International Journal of Engineering \& Technology, $7(4.5)(2018) 459-463$
International Journal of Engineering \& Technology
SPC
Website: www.sciencepubco.com/index.php/IJET
Research paper

\title{
Experimental Studies on Behavior of Keratin Based Human Hair Fiber - A New Reinforcing Material for Composites
}

\author{
Eshwara Prasad K. ${ }^{1}$, Divakara Rao P. ${ }^{2}{ }^{*}$, Udaya Kiran C. ${ }^{3}$ \\ ${ }^{1}$ Professor, Mechanical Engineering, JNTUH \\ ${ }^{2}$ Associate Professor, Mechanical Engineering, JBIET, Moinabad, Hyderabad \\ ${ }^{3}$ Professor, Mechanical Engineering, JBIET, Moinabad, Hyderabad \\ *Corresponding author E-mail: raodivakar_p@yahoo.co.in
}

\begin{abstract}
Composite materials are formed by two or more constituents at macroscopic level. Type and form of fiber plays a vital role in imparting required properties to the composite. Many researchers contributed to the development of artificial fiber composites which are not environmental friendly in nature. Sizable research is also done in the area of natural fiber composites. Human hair is a non-biodegradable waste available in abundant quantity across the world, but is rarely explored for applications in engineering fields. In the present study, a review on behavior of human hair fibers was made to understand their suitability as a reinforcing material in composites. Morphology of the hair fibers is reviewed and the density of the hair fibers was determined using Archimedes principle. Tensile strength of the hair fibers is experimentally estimated. Chemical resistivity and burning tests were conducted. Tensile and flexural properties of hair fiber reinforced polyester composite were experimentally determined and compared.
\end{abstract}

Keywords: Animal fiber; Composites; Feather fiber; Hair fiber; Properties

\section{Introduction}

Continuous technological advancements have helped mankind improve their standards of living, with the rapidness of development and research. However, certain technology also creates a negative environmental impact. Manufacturing of composites using artificial fibers such as glass fibers, carbon fibers etc., have provided novel materials with high strength to weight ratio. But they also pose a threat to the environment due to their non- biodegradable nature. Therefore efforts are invested in making use of naturally biodegradable and sustainable material that exist in nature rather than creating a new material. Bio-fibers serve as reinforcement in bio-composites enhancing the strength and stiffness to the resulting composite structures. Animal fibers such as chicken feather, human hair, hairs of other birds and animals are commonly described as a waste by-product and they are contributing to environmental pollution due to the disposal problems There are two main animal fiber disposal methods that exist. i)Burning and ii)Burying. Both of them have negative impact on the environment. Nature, source, origin and their physical and chemical composition of different natural fibers have been reviewed $[1,2]$. Much research has been done towards cellulose from vegetal sources but little focus is made in other potentially interesting compounds like keratin, which can be found in hair, nails, and feathers. In spite of good strength, low density and biodegradability, keratin has been studied only from the medical and textile point of view. A.L. Martinez-Herna et al. have carried spectroscopic analysis on keratin based chicken feather fiber [3].

Recent studies on the chicken feather waste demonstrated that waste can be a potential composite reinforcement. The composite reinforcement of the animal fibers offer much more effective way to solve environmental concerns compared to the traditional disposal methods. Some of the advantages of the animal fibers are inexpensive, renewable, and readily available in abundant quantity. The chicken feather fibers (CFF) as a composite reinforcement have certain desirable properties including lightweight, high thermal insulation, excellent acoustic properties, non-abrasive behavior and excellent hydrophobic properties. The CFF has the lowest density value compared to the all natural and synthetic fibers [47]. S. C. Mishra et al.[8] have studied the mechanical properties of feather fiber composites and identified possible chemical reactions taking place during composite making. Poultry feather behavior was analyzed and its mechanical properties were estimated by KB Jagadeeshgouda el al. [9]

Hair is a complex tissue consisting of several morphological components as shown in figure1 [10]. Each component in turn consists of several different chemical types. Therefore, hair is an integrated system in terms of its structure and its chemical and its physical behavior. The frictional behavior of hair is primarily related to the cuticle. The tensile behavior of human hair is determined by the cortex. 


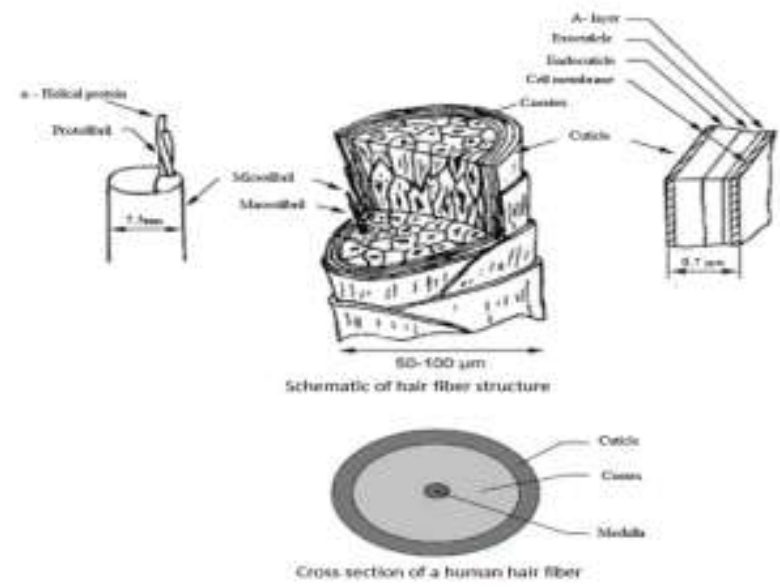

Fig. 1: Structure of Hair fiber [10]

Keratin is the primary constituent of human hair fiber. These keratins are proteins, polymers of amino acids. Keratin proteins form the cytoskeleton of all epidermal cells. Keratin proteins comprise $65-95 \%$ of the total hair fiber by weight. Mostly hair fibers are made of hard keratins which do not dissolve in water. Hard keratins are highly resistant to photolytic enzymes. Hair fiber durability and resistance to degradation under environmental stress comes from the linkage between the cystine molecules and keratin proteins that form disulfide chemical bonds. These bonds are very strong. Raw elements present in hair fiber are shown in table 1 and amino acids with their quantities present in normal hair fiber are shown in table 2 [10-12].

Table 1: Raw elements present in Hair [10-12]

\begin{tabular}{|c|c|}
\hline Element Name & Quantity \\
\hline Carbon & $50.65 \%$ \\
\hline Oxygen & $20.85 \%$ \\
\hline Nitrogen & $17.14 \%$ \\
\hline Hydrogen & $6.36 \%$ \\
\hline Sulfur & $5.00 \%$ \\
\hline
\end{tabular}

Table 2: Amino acids present in Human hair [10-12]

\begin{tabular}{|c|c|}
\hline Amino Acid & Amount in residues extracted \\
\hline Cysteine & 17.5 \\
\hline Serine & 11.7 \\
\hline Glutamic acid & 11.1 \\
\hline Threonine & 6.9 \\
\hline Glycine & 6.5 \\
\hline Leucine & 6.1 \\
\hline Valine & 5.9 \\
\hline Arginine & 5.6 \\
\hline Aspartic acid & 5 \\
\hline Alanine & 4.8 \\
\hline Proline & 3.6 \\
\hline Isoleucine & 2.7 \\
\hline Tyrosine & 1.9 \\
\hline Phenylalanine & 1.4 \\
\hline Histidine & 0.8 \\
\hline Methionine & 0.5 \\
\hline
\end{tabular}

\section{Experimental}

\subsection{Cleaning of Human Hair}

Male and Female Indian Hindu religion people always offer their hair by shaving their head to the God as sacrifice upon fulfilling their wishes by the God. Most of the hair in India comes from the temples and rural villages. Hair from India is considered to be the highest quality as most of these women in rural India have natural, high quality hair that may have never been treated with chemicals. In the present study, human hair ranging from $8-16$ inches length was collected from different women pilgrims in the age group of
35- 40 years. These hair samples were procured from barbers working at a local temple located at Palasa, Srikakulam district, Andhra Pradesh, India. Collected human hair was thoroughly cleaned with detergent, washed with distilled water and then sun dried.

\subsection{Estimation of Diameter and Density of Hair Fiber}

Diameter of the hair fibers were measured using optical microscope at Lucid laboratories Pvt Ltd, Balanagar, Hyderabad and are shown in figure 2 . The average readings of ten samples were presented in the table 3. Similar results were also reported by Zhenxing $\mathrm{Hu}$ et al.[13]

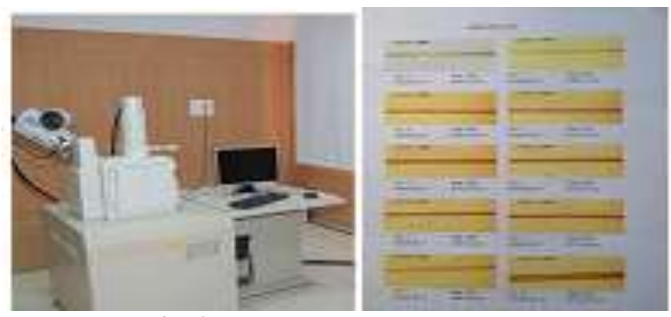

Fig. 2: Measurement of Hair diameter

Table 3: Hair Diameter and its Mechanical Properties

\begin{tabular}{|c|c|c|c|c|}
\hline $\begin{array}{c}\text { Sample } \\
\text { No }\end{array}$ & $\begin{array}{c}\text { Diameter } \\
\text { (Micro } \\
\text { meter) }\end{array}$ & $\begin{array}{c}\text { Breaking } \\
\text { Load } \\
\text { in (grams) }\end{array}$ & $\begin{array}{c}\text { Elongation } \\
\text { at break } \\
\text { in \% }\end{array}$ & $\begin{array}{c}\text { Tensile } \\
\text { Stress } \\
(\mathrm{MPa})\end{array}$ \\
\hline 1 & 90 & 86.2 & 21.5 & 132.991 \\
\hline 2 & 80 & 82.2 & 31.6 & 160.506 \\
\hline 3 & 80 & 80 & 33.3 & 156.21 \\
\hline 4 & 70 & 82.9 & 38 & 211.426 \\
\hline 5 & 70 & 80.9 & 27.3 & 206.325 \\
\hline 6 & 70 & 83.2 & 35.2 & 212.191 \\
\hline 7 & 60 & 68.7 & 32.4 & 238.481 \\
\hline 8 & 70 & 80 & 28.2 & 204.03 \\
\hline 9 & 80 & 76.4 & 32.9 & 149.181 \\
\hline 10 & 73 & 78.3 & 25.0 & 183.618 \\
\hline Average & 80 & 81.63 & 30.54 & 180.826 \\
\hline
\end{tabular}

Density of the hair fibers is estimated experimentally using Archimedes principle as shown in figure 3 . Five samples of hair were taken and mass is measured using electronic balance. The samples were then immersed in glass tubes of known volume. The increase in volume was recorded and the density is estimated using equation 1 and shown in table 4.

Density of hair = Mass of hair/ Volume of hair

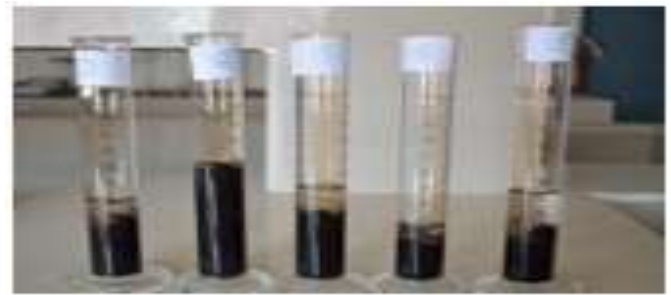

Fig.3: Measurement of Hair density using Archimedes principle

Table 4: Hair density

\begin{tabular}{|c|c|c|c|c|c|}
\hline $\begin{array}{c}\text { Sample } \\
\text { No. }\end{array}$ & $\begin{array}{c}\text { Mass } \\
\text { of } \\
\text { Hair } \\
( \\
\text { Grams })\end{array}$ & $\begin{array}{c}\text { Initial } \\
\text { reading } \\
\text { of water } \\
\text { level } \\
\text { in the } \\
\text { glass tube } \\
\text { in cc or } \\
\text { ml }\end{array}$ & $\begin{array}{c}\text { Final water } \\
\text { Level when hair } \\
\text { is immersed in } \\
\text { the water com- } \\
\text { pletely } \\
\text { in cc or ml }\end{array}$ & $\begin{array}{c}\text { Net } \\
\text { volume } \\
\text { of hair } \\
(\mathrm{cc})\end{array}$ & $\begin{array}{c}\text { Density } \\
\text { of hair } \\
=\mathrm{M} / \mathrm{V} \\
(\mathrm{g} / \mathrm{cc})\end{array}$ \\
\hline 1 & 12.23 & 40 & 49 & 9 & 1.36 \\
\hline 2 & 24.11 & 50 & 68 & 18 & 1.34 \\
\hline 3 & 16.98 & 40 & 52.5 & 12.5 & 1.36 \\
\hline 4 & 2.74 & 28 & 30 & 2 & 1.37 \\
\hline
\end{tabular}




\begin{tabular}{|l|l|l|l|l|l|}
\hline 5 & 1.31 & 51 & 52 & 1 & 1.31 \\
\hline \multicolumn{5}{|c|}{ Average Density of hair } \\
\hline
\end{tabular}

\subsection{Aspect ratio of Hair Fibers}

A fiber is characterized not only by its length to diameter ratio but by its near crystal sized diameter. Strength to density and stiffness to density ratios also indicate the effectiveness of a fiber in case of weight sensitive applications. Hair diameter commonly varies along the length. Length of the hair fiber varies with in a person and from person to person. Therefore aspect ratio of the human hair varies from 317.5- 6985 for general range of fiber lengths of 1inch - 22 inch respectively. Aspect ratios for a chicken feather fiber are reported as 600-3667 [9].

\subsection{Fiber Strength}

Tensile strength of the human hair fibers was measured on a universal testing machine at CIPET, Hyderabad. Fibers were held by adhesive tape and tested with a cross head speed of $1.3 \mathrm{~mm} / \mathrm{min}$. Fiber diameter measured with optical microscope is used to find the area of the fiber. The tensile strengths ranged from $150 \mathrm{MPa}$ to $238 \mathrm{MPa}$ and the results are tabulated in 3 .

\subsection{Chemical test of human Hair fibers}

Human hair fiber samples of known weight were tested with $5 \%$ $\mathrm{NaOH}, 2 \% \mathrm{Na}_{2} \mathrm{CO}_{3}, 1 \% \mathrm{HCl}$ and normal mineral water. The samples were soaked in different solutions in reagent bottles for time duration of $1 \mathrm{hr}, 6 \mathrm{hrs}, 12 \mathrm{hrs}$ and $24 \mathrm{hrs}$. The setup is shown in figure 4. After the specified time durations, the samples were reweighed and the results are summarized in table 5 .
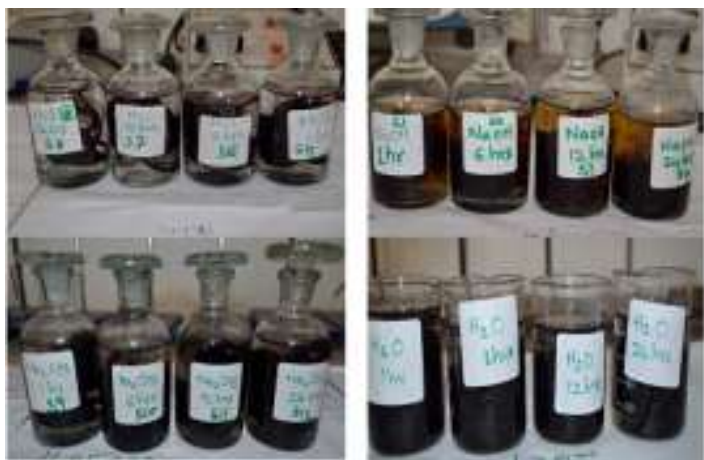

Fig. 4: Experimental arrangement of chemical test

Table 5: Chemical Test results of hair fibers

\begin{tabular}{|c|c|c|c|c|c|c|c|c|c|c|c|c|}
\hline \multirow[b]{2}{*}{$\begin{array}{c}\text { Sample } \\
\text { No }\end{array}$} & \multirow[b]{2}{*}{$\begin{array}{c}\text { Net } \\
\text { weight } \\
\text { of hair } \\
\text { fiber }\end{array}$} & \multicolumn{4}{|c|}{ Soaking solution } & \multirow{2}{*}{$\begin{array}{l}\text { Weight of } \\
\text { fibers - } \\
1 \mathrm{hr} \text { soak- } \\
\text { ing }\end{array}$} & \multirow{2}{*}{$\begin{array}{l}\text { Weight of } \\
\text { fibers - } \\
6 \mathrm{hr} \text { soak- } \\
\text { ing }\end{array}$} & \multirow[b]{2}{*}{$\begin{array}{l}\text { Weight of } \\
\text { fibers - } 12 \\
\text { hr soaking }\end{array}$} & \multirow[b]{2}{*}{$\begin{array}{l}\text { Weight of } \\
\text { fibers - } 24 \mathrm{hr} \\
\text { soaking }\end{array}$} & \multirow[b]{2}{*}{$\begin{array}{l}\text { Weight } \\
\text { loss in } \\
\text { grams }\end{array}$} & \multirow[b]{2}{*}{$\begin{array}{c}\% \\
\text { weight } \\
\text { loss }\end{array}$} & \multirow[b]{2}{*}{$\begin{array}{l}\text { Weight } \\
\text { Loss/ } \\
\text { gain }\end{array}$} \\
\hline & & Water & $\begin{array}{c}5 \% \\
\mathrm{NaOH}\end{array}$ & $\begin{array}{c}2 \% \\
\mathrm{Na}_{2} \mathrm{CO}_{3}\end{array}$ & $\begin{array}{c}1 \% \\
\mathrm{HCl}\end{array}$ & & & & & & & \\
\hline s1 & 0.77 & & $\sqrt{ }$ & & & 0.51 & & & & 0.26 & 33.8 & Loss \\
\hline s2 & 0.78 & & $\sqrt{ }$ & & & & 0.08 & & & 0.7 & 89.7 & Loss \\
\hline s3 & 0.94 & & $\sqrt{ }$ & & & & & 0.03 & & 0.91 & 96.8 & Loss \\
\hline s4 & 1.51 & & $\sqrt{ }$ & & & & & & $\begin{array}{c}\text { completely } \\
\text { dissolved }\end{array}$ & 1.51 & 100 & Loss \\
\hline s5 & 1.89 & & & & $\sqrt{ }$ & 1.84 & & & & 0.05 & 2.65 & Loss \\
\hline s6 & 1.73 & & & & $\sqrt{ }$ & & 1.67 & & & 0.06 & 3.47 & Loss \\
\hline s7 & 1.07 & & & & $\sqrt{ }$ & & & 1.05 & & 0.02 & 1.87 & Loss \\
\hline s8 & 1.02 & & & & $\sqrt{ }$ & & & & 0.98 & 0.04 & 3.92 & Loss \\
\hline s9 & 2.44 & & & $\sqrt{ }$ & & 2.34 & & & & 0.1 & 4.1 & Loss \\
\hline s10 & 3.76 & & & $\sqrt{ }$ & & & 3.79 & & & -0.03 & -0.8 & Gain \\
\hline s11 & 2.25 & & & $\sqrt{ }$ & & & & 2.3 & & -0.05 & -2.22 & Gain \\
\hline s12 & 2.2 & & & $\sqrt{ }$ & & & & & 2.7 & -0.5 & -22.7 & Gain \\
\hline s13 & 2.38 & $\sqrt{ }$ & & & & 2.33 & & & & 0.05 & 2.1 & Loss \\
\hline s14 & 2.93 & $\sqrt{ }$ & & & & & 2.92 & & & 0.01 & 0.34 & Loss \\
\hline s15 & 1.53 & $\sqrt{ }$ & & & & & & 1.54 & & -0.01 & -0.65 & Gain \\
\hline s16 & 1.38 & $\sqrt{ }$ & & & & & & & 1.4 & $\begin{array}{l}-0.02 \\
\end{array}$ & -1.45 & Gain \\
\hline
\end{tabular}

\subsection{Burning test}

Burning test was conducted to know the behaviour of the hair fibers when they are exposed to burning.

\subsection{Preparation and testing of Human hair reinforced polyester composite sheet}

Hair fibers cut into $40 \mathrm{~mm}$ length and were spread with random orientation in the mould. The polyester resin along with the catalyst and accelerators in required quantities were mixed thoroughly as per the procedure and poured in to the mould to fill it. Sufficient care was taken to have uniform distribution and full impregnation of fiber in the resin. The mould was then closed with other half part of mould, clamped tightly and was kept for 24 hours at room temperature as polyester cures completely in 24 hours of time. The composite sample sheets of $40 \mathrm{~mm}$ fiber length with different weight ratios were fabricated in the present study to test its mechanical properties.

\subsubsection{Tensile Test}

Test specimens were cut from the completely cured composite sheet as per ASTM D638 standard. The tensile tests were carried out at CIEPT using Autograph AG15, Shimazdu 0-50 kN range with an accuracy of $0.1 \mathrm{~N}$ and cross hear speed of $1.3 \mathrm{~mm} / \mathrm{min}$. For each test, 5 specimens were used, and the average value of these results is tabulated in table 6 . Test specimen under test is shown in figure 5 .

\subsubsection{Flexural Test}

Composite specimens were prepared as per the standard test methods for three - point flexural tests. The composite samples of rectangular shape were prepared according to ASTM D 790 for three-point flexural test [14]. Flexural tests were conducted on a Nano Servo Hydraulic UTM Plug N Play machine (ITW BISS make) of $25 \mathrm{kN}$ capacity available at CBIT, Hyderabad with a cross head speed of $1.5 \mathrm{~mm} / \mathrm{min}$ with $64 \mathrm{~mm}$ support span. The test results are summarized in table 6 . Values given in the table represents average readings of five test specimens. All the tests were conducted at room temperature. Test specimen under test is shown in figure 5 . 

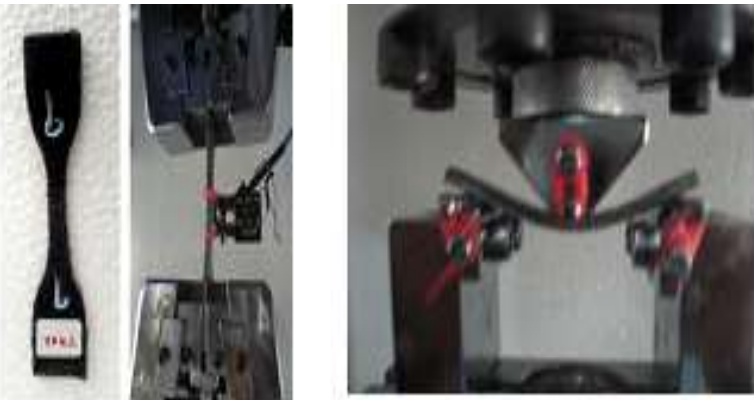

Fig. 5: Tensile and Flexural Testing of composite

Table 6: Tensile and flexural properties of Human hair composite

\begin{tabular}{|c|c|c|c|}
\hline S.No. & $\begin{array}{c}\text { Fiber weight } \\
\text { Ratio } \\
(\%)\end{array}$ & $\begin{array}{c}\text { Tensile } \\
\text { Stress } \\
(\mathrm{MPa})\end{array}$ & $\begin{array}{c}\text { Flexural } \\
\text { stress } \\
(\mathrm{MPa})\end{array}$ \\
\hline 40HHRC05 & 5.1 & 12.00 & 28.4 \\
\hline 40HHRC10 & 9.85 & 17.87 & 35.6 \\
\hline 40HHRC15 & 15.62 & 22.12 & 43.2 \\
\hline 40HHRC20 & 20.6 & 27.00 & 37.6 \\
\hline 40HHRC25 & 26.2 & 25.30 & 36.0 \\
\hline 40HHRC30 & 31.4 & 18.64 & 27.1 \\
\hline 40HHRC35 & 35.5 & 11.52 & 13.6 \\
\hline
\end{tabular}

\section{Results and Discussions}

It is observed from the table 3 that average density of human hair fibers is $1.34 \mathrm{~g} / \mathrm{cc}$. The difference in density among different samples may be due to the fact that hair samples collected from different people. The hairs of different people will have different density values depending upon the structure of the fiber. Compared with other natural fibers, like wool $1.3 \mathrm{~g} / \mathrm{cc}$, silk $1.17 \mathrm{~g} / \mathrm{cc}$, cotton $1.5-1.6 \mathrm{~g} / \mathrm{cc}$, jute $1.3 \mathrm{~g} / \mathrm{cc}$ and coir $1.2 \mathrm{gcc}$, density of hair fiber is in line with its counter fibers.

Generally, the aspect ratio of the hair fibers is much higher when compared to that of chicken feather and other bird feathers. Higher aspect ratios of fibers lead to better performance when impregnated into the resin.

From table 4, it is observed that Hair fiber load carrying capacity ranges from $150-238 \mathrm{MPa}$. The variation is mainly due to hair quality and thickness variations from person to person and also changes due to chemical treatment of the fibers. Still the hair fibers exhibit higher load bearing capacities under tensile loading. Hence this can be used as a reinforcing material in composite materials. The hair fibers also undergo large elongation before failure. The $\%$ elongation ranges from $21-35 \%$.

Moisture sensitivity is one of the major serious problems that is associated with the natural fibers when compared to artificial fibers. Natural fibers either swell or rot when exposed to various solutions. Hair fibers are tested for this behaviour by soaking them in $5 \% \mathrm{NaOH}, 2 \% \mathrm{Na} 2 \mathrm{CO} 3,1 \% \mathrm{HCl}$ and normal mineral water for $1 \mathrm{hr}, 6 \mathrm{hrs}, 12 \mathrm{hrs}$ and $24 \mathrm{hrs}$. From table 5, it is observed that human hair gained weight from $0.8 \%$ to $22.7 \%$ when soaked in $2 \%$ $\mathrm{Na} 2 \mathrm{CO} 3$ for $1 \mathrm{hr}$ and $24 \mathrm{hrs}$ respectively. Whereas the weight loss in case of soaking in $\mathrm{NaOH}$ is $33.8 \%$ for $1 \mathrm{hr}$ and human hair was completely diluted when soaked for $24 \mathrm{hrs}$. But for $\mathrm{HCl}$ solution the weight loss is only $4 \%$ and for water, it is almost non reactant. Hair is having the tendency of fusing when brought nearer to the flame and fuses and burns when kept in the flame. But when it is taken out of the flame it supports combustion for short period. During burning, it gives odour of burning a chicken feather. Colour of the ash is observed to be very black and is crushed to only size of the sand granules. The burning phenomena are shown in figure 6 .
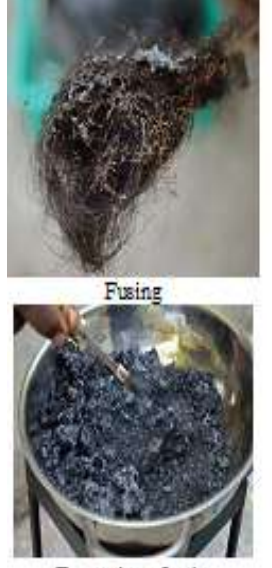

Formation of coke
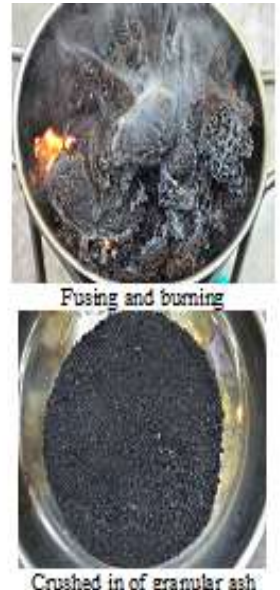

Crushed in of granular ash

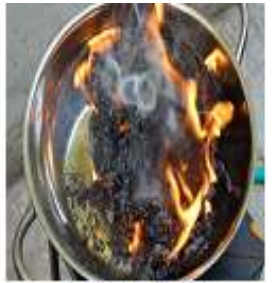

Sustained burning

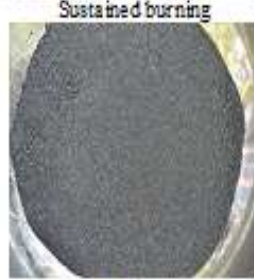

Crushad in to Powder form
Fig. 6: Burning behaviour of hair fiber

Tensile and flexural stresses of the composite made of $40 \mathrm{~mm}$ length of fibers for different fiber loadings are shown in figure 7.

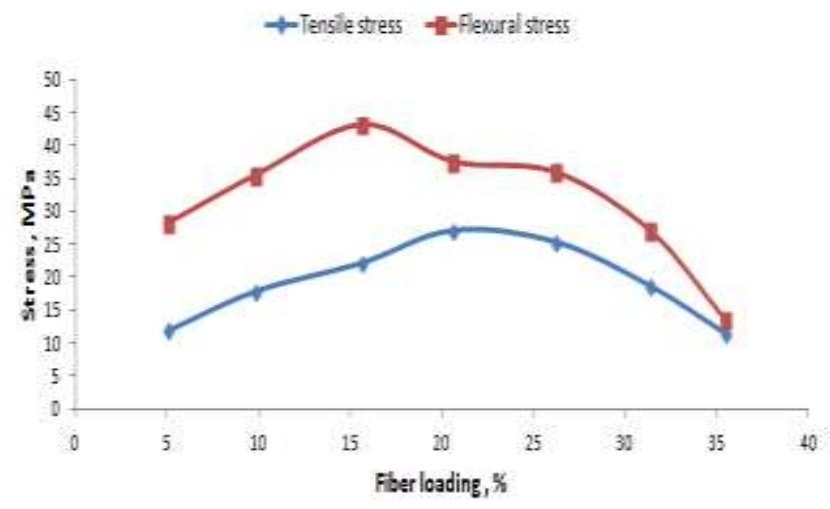

Fig. 7: Variation of Tensile and Flexural Stress with fiber loading

It is evident from the figure 7 that both tensile and flexural stresses are increasing with increasing fiber loading. Maximum stresses are observed between 15\%- $20 \%$ fiber loadings. Decrease in stresses at higher fiber loadings is due to improper impregnation and high void volume. Also at low fiber loading, even less loads are high enough to break the fibers. These broken fibers can be regarded as an array of holes in the composite. As explained in the composite theory [15], the reinforcing becomes effective only when the fiber loading exceeds the critical value. There is also a maximum fiber content beyond which the properties of the composite tend to deteriorate $[12,13]$. This is due to the fact that at higher fiber weight fractions, fiber to fiber spacing becomes so small that the stress transfer between the fiber and matrix becomes ineffective [10].

\section{Conclusion}

Human hair fiber is a sustainable waste material abundantly available in the market. Its recycling is very essential to the environment due its non-bio-degradable nature. Its low density, easy availability and non reactant to water make human hair as an alternative reinforcing fiber material. Tensile strength of $27 \mathrm{MPa}$ and flexural strength of $43.2 \mathrm{MPa}$ make the human hair reinforced composite material a competitor to other natural and glass fiber composite materials. 


\section{References}

[1] J. N. McGovern, "Fibers, Vegetable", in: Encyclopedia of Polymer Science and Engineering, vol. 7, John Wiley \&Sons, New York 1987, pp: 17

[2] S. K. Batra, "Other long vegetable fibers", in Handbook of Fiber Chemistry, 2nd Edn., M. Lewin, E. M. Pearce, Eds., Marcel Dekker, Inc., New York 1998, pp: 505

[3] A.L. Martinez-Hernandez, C. Velasco-Santos, M. De Icaza, V.M. Castano, "Microstructural characterisation of keratin fibres from chicken feathers", International Journal of Environment and Pollution, Jan 2005, Vol. 23, Issue 2, pp: 162-178.

[4] J.R. Barone, W.F. Schmidt, F.E. Liebner, "Compounding and molding of polyethylene composites reinforced with keratin feather fiber", Composites Science and Technology 65 (2005), pp:683-692.

[5] T.A. Bullions, D. Hoffman, R.A. Gillespie, J.P. O’Brien, A.C.Loos "Contributions of feather fibres and various cellulose fibres to the mechanical properties of polypropylene matrix composites", Composite Science and Technology 66 (2006), pp: 102-114.

[6] S. Huda, Y. Yang, "Composites from ground chicken quill and polypropylene", Composites Science and Technology 68 (2008), pp: 790-798.

[7] N. Reddy, Y. Yang, "Structure and properties of chicken feather barbs as natural protein fibres", Journal of Polymers and The Environment 15/2 (2007) 81-87.

[8] S. C. Mishra, Nadiya Bihari Nayak, and Alok Satapathy, "Investigation on Bio-waste Reinforced Epoxy Composites", Journal of Reinforced Plastics and Composites 2009, Volume: 29 issue: 19, page(s): 3016-3020

[9] KB Jagadeeshgoud, P.Ravinder Reddy, K Eswara Prasad, "Experimental study of behavior of poultry feather fiber - A reinforcing material for composites", International journal of research in engineering and Technology, Vol. 03, Issue 02, Feb.2014

[10] P. Divakara Rao, C. Udaya Kiran, K. Eshwara Prasad, "Effect of Fiber Loading and Void Content on Tensile Properties of Keratin Based Randomly Oriented Human Hair Fiber Composites", International Journal of Composite Materials,ISSN: 2166-479X e-ISSN: 2166-4919 2017; 7(5): 136-143 doi:10.5923/j.cmaterials.20170705.02

[11] Fuchs E. "Keratins and the skin", Annu Rev Cell Dev Biol. 1995; 11:123-53.

[12] Yu J, Yu DW, Checkla DM, Freedberg IM, Bertolino AP. "Human hair keratins", J Invest Dermatol. 1993 Jul;101(1 Suppl):56S-59S.

[13] Zhenxing Hu, Gaosheng Li, Huimin Xie, Tao Hua, Pengwan Chen, et al. "Measurement of Young's modulus and Poisson's ratio of human hair using optical techniques", Proc SPIE 7522, Fourth International Conference on Experimental Mechanics, 75222Q. 2010;7522 (75222Q):9.

[14] G. Koronis et al. "Predicting the flexural performance of woven flax reinforced epoxy composites using design of experiments," Materials Today Communications 13 (2017) 317-324.

[15] Harris B. "Engineering composite materials", Cambridge: Cambridge University Press; 1999.

[16] "Porosity and stiffness", Composites Science and Technology. 2009; 69 (7-8):1057-1069.

[17] Madsen B, Hoffmeyer P, Lilholt H. "Hemp yarn reinforced composites - II. Tensile properties", Composites Part A: Applied Science and Manufacturing. 2007; 38 (10):2204-2215. 